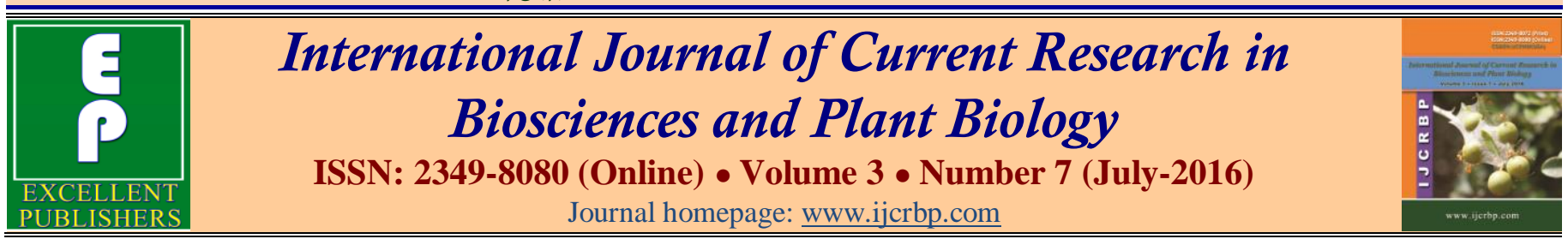

Original Research Article

doi: http://dx.doi.org/10.20546/ijcrbp.2016.307.016

\title{
Identification of Potential Crosses for Sesame Breeding
}

\author{
Swapan K. Tripathy*, D. R. Mishra, D. Mishra, S. K. Mohanty, S. Dash, S. Panda, \\ M. R. Mohanty, K. R. Reshmi Raj, Kartik Ch. Pradhan, D. Swain and P. M. Mohapatra
}

Department of Agricultural Biotechnology, College of Agriculture, Orissa University of Agriculture and Technology, Bhubaneswar (India)

*Corresponding author.

\begin{abstract}
Analysis of variance revealed significant difference for both parent as well as $F_{1} s$ in case of all traits indicating the fact that the parents were genetically highly diverse and those also produced widely diverse $F_{1}$ hybrids. The hybrids, in general, show appreciable advantage over the parents in plant height, number of capsules/plant and seed yield/plant. All agronomic traits including seed yield revealed wide range of genetic variability among crosses. Pratap, CST 785, E 8 and Phule Til-1 were shown to be one of the parents which topped important agro-economic traits in mean performance. CST $785 \times$ E8 recorded as the highest yielding $F_{1}(7.82)$ followed by $\mathrm{T} 13 \times \mathrm{E} 8$, but these revealed poor status for oil content $(\leq 50.0 \%)$. TC 25 , RT 103 and TMV 5 are rich in oil content ( $\geq 54.0 \%$ ), but none of these were involved to excel oil content in the above $F_{1}$ crosses indicating role of specific parental combination (non-allelic gene interaction) in expression of higher oil content.
\end{abstract}

\section{Article Info}

Accepted: 18 June 2016

Available Online: 06 July 2016

\section{Keywords}

Mean performance

Morpho-economic traits

Sesamum indicum $\mathrm{L}$.

\section{Introduction}

Sesame (Sesamum indicum L, Family: Pedaliaceae) is the queen of high quality vegetable oils for human consumption as it contains high levels unsaturated fatty acids and antioxidants e.g., sesamol, sesamin, sesamolin and sesaminol (Nupur et al., 2010). Besides, sesame oil is rich in carbohydrate, protein, calcium and phosphorus and used as a source of biodiesel with superior environmental performance (Ahmed et al., 2010). Its unique semi-drying property makes it suitable for use in paint formulation (Bedigian, 2003). In addition, sesame seed is traditionally used for direct consumption as well as for confectioneries, cookies, cake and margarine and in bread making. It is also useful in the manufacture of soaps, cosmetics, perfumes, insecticides and pharmaceutical products.
India shares largest area (35\%) under sesame and ranked second largest producer of sesame seeds $(13.1 \%)$ in the world with an estimated production of 636,000 metric tonnes. Sesame harbour comparatively high oil content ( $55 \%$ of dry seed) among the oilseed crops, but, it suffers a serious setback in terms of productivity $(368 \mathrm{~kg} / \mathrm{ha})$ as compared to world average (489kg/ha). This is due to large scale cultivation of low yielding varieties in marginal lands. High levels of morphological genetic diversity do exist in sesame (Arriel et al., 2007) but this has not been fully harnessed for genetic improvement of the existing cultivars through hybridization. Superior performing hybrids for seed yield and yield components in sesame have been reported by many workers (Mishra and Sikarwar, 2001; Saravannan and Nadarajan, 2002; Prajapati et al., 2010; and Padma Sundari and Kamala, 2012). Besides, some of the elite crosses may be amenable for selection of high yielding 
transgressive segregants in $\mathrm{F}_{2}$ and follow up selfing generations. Therefore, in the present investigation, an attempt has been taken to identify most desirable potential crosses for genetic improvement in sesame following half diallel mating design.

\section{Materials and methods}

Twelve popular parental genotypes of sesame collected from different states of India were tested along with all possible cross combinations in RBD with three replications to raise $F_{1}$ generation. Emasculation and pollination were carried out in late afternoon using Fevicol method (Das, 1990) for all possible combinations of parental genotypes in a $12 \times 12$ half diallel mating design (Parents + crosses without reciprocals). Each parental genotype and cross was grown in five rows of $3.5 \mathrm{~m}$ length with a spacing of $30 \times 10 \mathrm{~cm}$. Observations on days to initial flowering, days to cessation of flowering, duration of flowering, days to maturity, height to first capsule $(\mathrm{cm})$, plant height $(\mathrm{cm})$, number of primary branches/plant, number of capsule/plant, capsule length $(\mathrm{cm})$, capsule breadth $(\mathrm{cm})$, number of seeds/capsule, 500-seed weight (g), oil content $(\%)$ and seed yield/plant $(\mathrm{g})$ were recorded per replication. The data were analysed as per standard statistical methods of Singh and Choudhury (1985) to gauge the extent of genetic variability among all possible $\mathrm{F}_{1} \mathrm{~s}$ as compared to parental performance for all morphoeconomic traits including oil content and seed yield.

\section{Results and discussion}

TMV 5 was shown to have maximum number of capsules/plant (21.4). Vinayak, Pratap, Madhabi and E 8 were characterized to have significantly longer capsules. Seeds/capsule ranged from 54.0 in B67 and TMV5 to a maximum of 87.8 seeds in Pratap. Besides, Madhabi and E 8 also exhibited higher number of seeds/capsule. Among the present set of parental genotypes, BS 5-18-6, CST 785 and Phule Til-1 bore significantly high 500seed weight (Table 1).

Oil content is the single most economic product in sesame. Out of twelve genotypes, oil content in seed was significantly high (around 54.5\%) in TC 25, CST 785, RT 103 and TMV 5. Seed yield ranged from 2.1g (T 13) to as high as $3.6 \mathrm{~g}$ (CST 785). Considering both oil content and seed yield, CST 785, TMV 5 and TC 25 may be considered elite genotypes.

Highly significant differences among the parents (P), hybrids $\left(F_{1}\right)$ and parents vs. hybrids for most of the characters studied (Table 2) indicated validity of the experiment. Analysis of variance revealed significant difference for both parent as well as $F_{1} s$ in case of all traits. Thus, it is evident that the parents were genetically highly diverse and those also produced widely diverse $\mathrm{F}_{1}$ hybrids (Nayak, 2008). Significance of parents vs. F 's was shown for all characters except days to initial flowering, days to cessation of flowering, height to first capsule, 500-seed weight and oil content which envisaged the presence of higher quantum of overall heterosis in respect of most of the characters studied. This is also evident from Table 2, showing mean and range over all the parents as well as the $\mathrm{F}_{1}$ 's, and $\left(\bar{F}_{1}-\bar{P}\right)$ for characters except days to cessation of flowering, period of flowering, height to first capsule, capsule breadth and oil content. It is further observed that overall $F_{1}$ performance differed considerably from that of the parents in important traits like number of primary branches/plant, number of capsules/plant and seed yield/plant thereby indicating high overall heterosis in desired direction. This was clearly revealed from positive differences of the magnitude $\left(\bar{F}_{1}-\bar{P}\right)$ and \% increase over the parent for these traits (31.69-54.54\%). The magnitude of upper limit of the ranges in the $\mathrm{F}_{1} \mathrm{~s}$ were higher than that in the parents in all agro-economic characters except capsule breadth; and it was much prevalent in plant height, number of capsules/plant and seed yield/plant. This is indicative of the fact that the hybrids, in general show appreciable advantage over the parents in those traits. Behera (2009) did similar studies in $\mathrm{F}_{1}$.

The estimate of coefficient of variation (CV) was less than or around $10 \%$ (Table 2) in all characters except days to initial flowering $(45.26 \%)$, number of primary branches $(24.03 \%)$, number of capsules/plant (16.59\%) and seed yield/plant (17.31\%). The low CV estimates in most of the characters justify the experimental precision. Whereas, the characters e.g., DIF and NPB which revealed relatively high $\mathrm{CV}$ estimates is highly versatile under micro changes of environment.

All agronomic traits including seed yield had shown wide range of genetic variability in both positive and negative direction as revealed from their overall range (Table 3). Among these, plant height, height to first capsule, number of primary branches, number of capsules per plant, number of seeds per capsule and seed yield per plant exhibited very high genetic variability indicating the scope for selection of high yielding hybrids from the present set of 66 crosses in diallel mating design. 
Table 1. Mean performance of 12 parental genotypes for different agro-economic traits including seed yield.

\begin{tabular}{|c|c|c|c|c|c|c|c|c|c|c|c|c|c|c|c|}
\hline Characters & $\begin{array}{l}\hat{6} \\
1\end{array}$ & $\underset{\Xi}{\stackrel{M}{\pi}}$ & 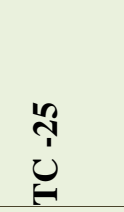 & $\begin{array}{l}\infty \\
0 \\
0 \\
0\end{array}$ & 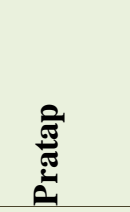 & 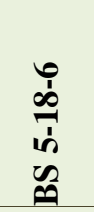 & 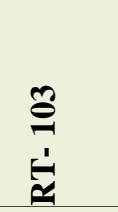 & $\sum_{i}^{n}$ & $\frac{m}{7}$ & 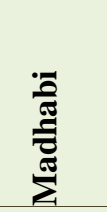 & $\begin{array}{l}\underset{I}{D} \\
\frac{0}{\Xi} \\
\underline{E}\end{array}$ & 我 & 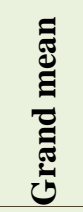 & $\begin{array}{l}\text { se } \\
\text { in } \\
0\end{array}$ & $\frac{2}{0}$ \\
\hline Days to initial flowering & 38.7 & 37.0 & 30.7 & 36.0 & $40.7 *$ & 36.7 & 29.7 & $40.3 *$ & 36.0 & 32.7 & $40.0 *$ & $40.3^{*}$ & 36.5 & 2.95 & 4.01 \\
\hline $\begin{array}{l}\text { Days to cessation of } \\
\text { flowering }\end{array}$ & 62.3 & 63.0 & 65.7 & 64.7 & $71.7 *$ & 61.7 & 59.7 & $71.0 *$ & 66.0 & 60.7 & 69.7 & 70.0 & 65.5 & 5.08 & 6.90 \\
\hline Period of flowering & 23.7 & 26.0 & $35.0 *$ & 28.7 & 31.0 & 25.0 & 30.0 & 30.7 & 30.0 & 28.0 & 29.7 & 29.7 & 28.9 & 5.51 & 7.49 \\
\hline Days to maturity & 75.0 & 76.7 & $71.3 * *$ & 78.3 & $83.7 * *$ & 72.7 & $69.3 * *$ & $83.0 * *$ & $80.3^{*}$ & 72.7 & 79.7 & $81.3 *$ & 77.0 & 3.35 & 4.56 \\
\hline Plant height & 93.1 & 100.4 & 95.7 & 97.7 & 106.1 & 90.0 & 92.6 & 107.5 & 93.1 & 93.8 & $113.8 * *$ & 109.4 & 99.4 & 10.19 & 13.85 \\
\hline Height to first capsule & 56.8 & 58.4 & 48.6 & 48.7 & 65.8 & 51.1 & 52.9 & $71.2 *$ & 51.0 & 56.5 & $70.9 *$ & 64.0 & 57.9 & 10.24 & 13.91 \\
\hline No of primary branches & 1.8 & 1.5 & 1.7 & 1.4 & 0.1 & 1.2 & 1.3 & $3.0 * *$ & 0.6 & 1.9 & 1.1 & 1.6 & 1.42 & 0.84 & 1.15 \\
\hline No of capsules per plant & 16.1 & 16.9 & 17.8 & 19.5 & 11.5 & 12.8 & 15.6 & $21.4^{*}$ & 12.9 & 15.2 & 16.4 & 17.9 & 16.2 & 5.15 & 7.01 \\
\hline Capsule length & 2.2 & $2.7 * *$ & 2.4 & 2.5 & $3.0 * *$ & 2.4 & 2.4 & 2.3 & 2.3 & $2.7 * *$ & 2.5 & $2.6^{*}$ & 2.5 & 0.13 & 0.18 \\
\hline Capsule breadth & 0.8 & 0.8 & 0.8 & 0.8 & $1.1 * *$ & 0.8 & 0.8 & 0.8 & 0.8 & 0.8 & $0.9 * *$ & 0.8 & 0.8 & 0.03 & 0.04 \\
\hline No of seeds per capsule & 54.1 & 69.3 & 64.8 & 66.6 & $87.8 * *$ & 60.9 & 60.1 & 53.8 & 58.3 & $69.9 *$ & 64.7 & $67.0 *$ & 64.7 & 4.75 & 6.45 \\
\hline 500 Seed weight & 1.3 & 1.3 & 1.4 & $1.5^{*}$ & 1.4 & $1.5^{*}$ & 1.4 & 1.4 & 1.4 & 1.3 & $1.5^{*}$ & 1.4 & 1.4 & 0.10 & 0.14 \\
\hline Oil content & 49.9 & 51.3 & $54.6 * *$ & $53.8^{*}$ & 52.0 & 47.2 & $54.8 * *$ & $54.0 *$ & 51.5 & 51.4 & 52.7 & 44.2 & 51.4 & 2.24 & 3.04 \\
\hline Seed yield per plant & 2.3 & 3.1 & 3.0 & $3.6 * *$ & 2.9 & 2.3 & 2.7 & 3.1 & 2.1 & 2.7 & 3.2 & 3.3 & 2.86 & 0.52 & 0.71 \\
\hline
\end{tabular}


Table 2. Analysis of variance for combining ability for 12x12 half-diallel crosses.

\begin{tabular}{|c|c|c|c|c|c|c|c|c|c|c|c|c|}
\hline \multirow[b]{2}{*}{ Characters } & \multicolumn{5}{|c|}{ Mean sum of square } & \multirow[b]{2}{*}{ C.V. } & \multicolumn{2}{|c|}{ Parent(P) } & \multicolumn{2}{|c|}{$\operatorname{Hybrid}\left(F_{1}\right)$} & \multirow[b]{2}{*}{$\overline{\mathrm{F}}_{1}-\overline{\mathrm{P}}$} & \multirow[b]{2}{*}{$\begin{array}{l}\% \\
\text { increase }\end{array}$} \\
\hline & $\begin{array}{l}\text { Parent } \\
(11)^{\mathrm{a}}\end{array}$ & $\begin{array}{l}\mathbf{F}_{1} \\
(65)\end{array}$ & $\begin{array}{l}\text { Parent } \\
\text { vs } F_{1}(1)\end{array}$ & $\begin{array}{l}\text { Replica- } \\
\text { tion (2) }\end{array}$ & $\begin{array}{l}\text { Error } \\
(154)\end{array}$ & & Mean & Range & Mean & Range & & \\
\hline Days to initial flowering (DIF) & $479.5 * *$ & $1253.5 * *$ & 33.3 & $107.1^{*}$ & 287.2 & 45.2 & 36.55 & $29.7-40.3$ & 37.44 & $33.5-46.0$ & 0.89 & 2.43 \\
\hline $\begin{array}{l}\text { Days to cessation of flowering } \\
\text { (DCF) }\end{array}$ & $53.24 * *$ & $34.4 * *$ & 3.03 & $274.2 * *$ & 5.11 & 3.46 & 65.50 & $59.7-71.7$ & 65.23 & $58.67-73.0$ & -0.27 & -0.41 \\
\hline Period of flowering (DCF-DIF) & $5.653 * *$ & $18.5^{* *}$ & $48.9 * *$ & $139.3 * *$ & 4.83 & 7.88 & 28.94 & $25.0-35.0$ & 27.87 & $23.0-35.0$ & -1.07 & -3.69 \\
\hline Days to maturity (DM) & $68.66 * *$ & $28.5^{* *}$ & $15.34 *$ & $233.5^{* *}$ & 2.48 & 2.02 & 77.00 & $69.3-83.7$ & 77.60 & $71.0-85.0$ & 0.60 & 0.78 \\
\hline Plant height (PHT) & $185.6 * *$ & $288.1 * *$ & $2408.3 * *$ & $5866.4 * *$ & 36.74 & 5.66 & 99.43 & $90.0-113.8$ & 106.95 & $91.67-130.4$ & 7.52 & 7.56 \\
\hline Height to first capsule (HFC) & $200.8 * *$ & $181.7 * *$ & 25.6 & $2678.3^{* *}$ & 21.52 & 8.10 & 57.96 & 48.6-71.1 & 57.19 & $44.18-74.6$ & -0.77 & -1.32 \\
\hline No. of primary branches (NPB) & $1.480 * *$ & $0.79 * *$ & $8.53 * *$ & $8.45 * *$ & 0.202 & 24.0 & 1.42 & $0.1-2.9$ & 1.87 & $1.08-3.27$ & 0.45 & 31.69 \\
\hline No of capsules per plant (NC/P) & $26.36^{*}$ & $66.79 * *$ & $2011.1 * *$ & $1412.2 * *$ & 14.64 & 16.6 & 16.17 & $11.4-21.4$ & 23.05 & $15.57-39.57$ & 6.88 & 42.54 \\
\hline Capsule length (CL) & $0.138 * *$ & $0.061 * *$ & $0.69 * *$ & $0.165 * *$ & 0.004 & 2.41 & 2.49 & $2.2-2.9$ & 2.62 & $2.34-3.01$ & 0.13 & 5.22 \\
\hline Capsule breadth (CB) & $0.023 * *$ & $0.003 * *$ & $0.0128 * *$ & $0.0034 * *$ & 0.0001 & 1.62 & 0.815 & $0.75-1.07$ & 0.80 & $0.73-0.89$ & -0.015 & -1.84 \\
\hline No of seeds per capsule (NS/C) & $244.6 * *$ & $43.52 * *$ & $115.3 * *$ & $71.4 * *$ & 3.309 & 2.73 & 64.76 & $53.83-87.8$ & 66.41 & $57.73-92.37$ & 1.65 & 2.54 \\
\hline 500 -Seed weight (SW) & $0.012 * *$ & $0.030 * *$ & 0.082 & $0.014 *$ & 0.0036 & 4.19 & 1.39 & $1.29-1.49$ & 1.43 & $1.15-1.62$ & 0.04 & 2.88 \\
\hline Oil content (OC) & $29.36 * *$ & $24.167 * *$ & 9.771 & 0.377 & 2.6628 & 3.19 & 51.45 & $44.2-54.7$ & 50.98 & $45.53-55.4$ & -0.47 & -0.91 \\
\hline Seed yield per plant (SY/P) & $1.055^{*}$ & $3.918 * *$ & $102.4 * *$ & $52.81 * *$ & 0.5860 & 17.3 & 2.86 & $2.14-3.61$ & 4.42 & $2.64-7.82$ & 1.56 & 54.54 \\
\hline
\end{tabular}


Table 3. Mean performance of possible crosses involving twelve parents of sesame following half -diallel mating design.

\begin{tabular}{|c|c|c|c|c|c|}
\hline Characters & Mean & $\begin{array}{l}\text { Over all } \\
\text { range }\end{array}$ & $\begin{array}{l}\text { Range of sig. } \\
\text { mean values }\end{array}$ & $\begin{array}{l}\text { Freq. of } \\
\text { elite } \\
\text { crosses }\end{array}$ & Promising desirable cross combinations \\
\hline $\mathrm{DIF}^{\mathrm{b}}$ & 37.44 & $33.5-46.0$ & $\begin{array}{l}40.33-46.0 \\
(\mathbf{3 3 . 5 0}-\mathbf{3 4 . 3 3 )}\end{array}$ & $8(6)$ & $\begin{array}{l}\text { B67xE8 }(44.0 * *) \text {, PratapxPhule Til-1 }(46.0 * *) \text {, Phule Til-1XE8 }(43.17 * *) \\
\text { TC 25x Pratap }(33.50 *), \text { CST 785x BS 5-18-6(33.67*), TC 25x RT 103(34.0*) }\end{array}$ \\
\hline $\mathrm{DCF}^{\mathrm{b}}$ & 65.23 & $58.67-73.0$ & $\begin{array}{l}70.67-73.0 \\
(\mathbf{5 8 . 6 7}-\mathbf{5 9 . 8 3 )}\end{array}$ & $4(5)$ & $\begin{array}{l}\text { PratapxTMV-5 }\left(73.0^{* *}\right) \text {, PratapxPhule Til-1 }\left(72.0^{*}\right) \text {, TMV5x Phule Til- } 1\left(72.17^{* *}\right) \\
\text { Vinayaka x TC 25(58.83*), CST 785x RT 103( 58.67*), B67xTC25(59.67*) }\end{array}$ \\
\hline $\mathrm{PF}$ & 27.87 & $23.0-35.0$ & $33.67-35.0$ & 2 & CST 785xT13 $(33.67 *)$, PratapxTMV $5\left(35.0^{* *}\right)$ \\
\hline $\mathrm{DM}^{\mathrm{b}}$ & 77.60 & $71.0-85.0$ & $\begin{array}{l}81.0-85.0 \\
(\mathbf{7 1 . 0}-\mathbf{7 3 . 8 3})\end{array}$ & $13(7)$ & $\begin{array}{l}\text { VinayakxPratap }(82.0 *) \text {, PratapxTMV } 5(83.83 * *) \text {, PratapxPhule Til-1 }(82.0 *) \\
\text { B67xTC25(71.67**), B67xMadhabi }(\mathbf{7 1 . 0 * * )} \text {, TC 25x BS 5-18-6(71.83**) }\end{array}$ \\
\hline $\mathrm{PHT}^{\mathrm{b}}$ & 106.95 & $91.67-130.4$ & $\begin{array}{l}119.4-130.4 \\
(91.67-96.19)\end{array}$ & $11(8)$ & $\begin{array}{l}\text { TMV 5x E8 (127.8**), T 13x E8(125.5**), Madhabix E8(130.4**) } \\
\text { TC 25x T 13( 91.19**), CST 785x T 13(92.67*) }\end{array}$ \\
\hline $\mathrm{HFC}$ & 57.19 & 44.18-74.6 & $\begin{array}{l}68.78-74.6 \\
(\mathbf{4 4 . 1 8}-\mathbf{7 4 . 6})\end{array}$ & $6(7)$ & $\begin{array}{l}\text { B67xVinayak(72.37**), PratapxMadhabi }\left(74.6^{* *}\right) \text {, Madhabi x E8(73.15**) } \\
\text { TC 25x T 13(44.19**), RT 103x T 13( 44.18**), Pratapx RT103(44.33**) }\end{array}$ \\
\hline NPB & 1.87 & $1.08-3.27$ & $2.72-3.27$ & 6 & CST 785xE8(3.27**), TMV 5xE8(3.18**), TC 25x E8(3.00**), \\
\hline $\mathrm{NC} / \mathrm{P}$ & 23.05 & $15.57-39.57$ & $28.25-39.57$ & 13 & CST 785xE8(39.57**), T13x E8(32.53**), VinayakxE8(31.90**), \\
\hline CL & 2.62 & 2.34-3.01 & 2.70-3.01 & 16 & CST 785x Phule Til-1(3.01**), CST 785x Pratap(2.98**), RT 103x Phule Til-1 (2.86**) \\
\hline $\mathrm{CB}$ & 0.80 & $0.73-0.89$ & $0.83-0.89$ & 12 & Pratap $\times$ T13 $(0.89 * *)$, CST $85 \times$ Phule Til-1 $\left(0.86^{* *}\right)$, Pratap×RT $103\left(0.85^{* *}\right)$ \\
\hline $\mathrm{NS} / \mathrm{C}$ & 66.41 & $57.73-92.37$ & $71.27-92.37$ & 9 & CST 785×Phule Til-1 (92.37**) \\
\hline SW & 1.43 & $1.15-1.62$ & $1.53-1.62$ & 16 & Pratap x Phule Til-1 (1.62**), TC 25×CST 785 (1.61**), Pratap×RT $103(1.61 * *)$ \\
\hline $\mathrm{OC}$ & 50.98 & $45.53-55.4$ & $53.23-55.40$ & 17 & CST 785×Pratap (58.40**), CST 785× Madhabi (58.23**), CST 785× Phule Til-1 (58.17**) \\
\hline $\mathrm{SY} / \mathrm{P}$ & 4.42 & 2.64-7.82 & 4.94-7.82 & 29 & $\begin{array}{l}\text { CST } 785 \times E 8\left(7.82^{* *}\right), \text { T13×E8 }\left(6.95^{* *}\right), \text { Pratap×RT } 103(6.67 * *), \text { Phule Til-1×E8 } \\
(6.38 * *)\end{array}$ \\
\hline
\end{tabular}

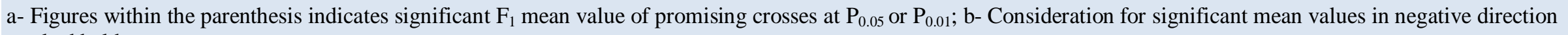
marked bold. 
Early flowering, early cessation of flowering, early maturity, dwarf plant habit and lower height to first capsule seem to be desirable plant architecture in sesame. In the present pursuit, six, five and seven $F_{1}$ hybrids out of 66 crosses had revealed significant negative value for days to initial flowering, days to cessation of flowering and days to maturity respectively (Table 3). Among these hybrids showing mean values for the above traits in negative direction; TC $25 \times$ Pratap, TC $25 \times \mathrm{RT} 103$, CST $785 \times$ BS $5-18-6$ exhibited very early in terms of days to initial flowering While crosses e.g., B67×TC25, Vinayaka×TC 25, CST 785×RT 103, BS 5-18-6×RT 103 came to cessation of flowering even within 59 days. Similarly, B67×TC25, B67×Madhabi and TC 25×BS 518-6 exhibited significantly early maturity (around 71 days) even at $1 \%$ level of significance. TC $25 \times \mathrm{T} 13$ was found to have lowest plant height $(91.19 \mathrm{~cm})$ and height to first capsule $(44.19 \mathrm{~cm})$ among the crosses. TC 25 and RT 103 had typical morphological architecture with early flowering (average 30.17days), early maturity (average 70.33days) and highest period of flowering (average 32.50days) with lowest height to first capsule $(50.76 \mathrm{~cm})$ and moderately higher number of primary branches (1.5 numbers/plant). These genotypes served as one of the parents in many promising $\mathrm{F}_{1}$ crosses.

Number of primary branches/plant, number of capsules/plant, capsule length, seeds/capsule and seed weight are the determinants for seed yield in sesame. It is worth to note that CST $785 \times \mathrm{E} 8$ excelled with first highest significant positive mean value for number of primary branches (3.27), and number of capsules/plant along (39.57) with seed yield/plant (7.82g) indicating its superiority in genetic potential for grain yield per se (Table 3). $F_{1}$ plants of the cross Pratap $\times T 13$ bore significantly bold capsules with average diameter of $89 \mathrm{~mm}$ while CST $785 \times$ Phule Til-1 had shown maximum number of seeds/capsule (92.37). Significantly higher seed weight was revealed in $F_{1}$ plants derived from crosses e.g., Pratap $\times$ Phule Til-1 (1.62g), TC $25 \times$ CST 785 (1.61g), Pratap $\times$ RT 103 (1.61g). In this context, it is worth to note that significantly bold capsule $(0.85 \mathrm{~cm})$ and consequent high 500 -seed weight $(1.61 \mathrm{~g})$ was revealed in case of Pratap $\times$ RT 103. Similarly, Senthil Kumar et al. (2003) also identified a few superior hybrids for exploitation of seed yield and other contributing characters.

In the present investigation, crosses e.g., CST $785 \times$ Pratap, CST $785 \times$ Madhabi and CST $785 \times$ Phule Til1 were shown to have significantly higher oil content $(\sim 58.0 \%)$ in seeds (Table 3$)$ as compared to the parents e.g., TC 25, RT 103 and TMV 5 which are rich in oil content ( $\geq 54.0 \%$ ) (Table 1$)$. Thus, it clearly revealed that none of these parents are involved to excel oil content in the above $F_{1}$ crosses indicating role of specific parental combination (non-allelic gene interaction) in expression of higher oil content. Further, it is interesting to note that 29 out of 66 cross combinations excelled significantly in seed yield/plant. CST $785 \times \mathrm{E} 8$ recorded as the highest yielding $F_{1}$ (7.82) followed by T13×E8, Pratap $\times$ RT 103 and Phule Til- $1 \times$ E8 but revealed poor status for oil content $(\leq 50.0 \%)$. Pratap, CST 785, E 8 and Phule Til-1 were shown to be one of the parents which excelled in mean performance of important agro-economic traits (Table 1). Phule Til-1 and Pratap were in fact ranked first and second in general combining ability (additive gene interaction), while CST 785 and E8 had shown poor in GCA estimates (Mishra, 2016). These were involved in production of some of the above heterotic hybrids in combination with other parents (both additive and non additive gene interaction), while excitingly high heterotic status in CST $785 \times E 8$ resulting highest yielding $F_{1}$ mean performance could be primarily due to non additive gene interaction. These potential cross combinations may be sorted out for sesame breeding following reciprocal recurrent selection (Solanki and Gupta, 2003).

\section{Conflict of interest statement}

Authors declare that they have no conflict of interest.

\section{References}

Ahmed, M., Khan, M.A., Zafar, M., Sultana, S., 2010. Environment-friendly renewable energy from sesame biodiesel. Energ. Source. Part A-32(2), 187-197.

Arriel, N.H.C, Mauro, A.O.D., Arriel, E.F., Trevisoli, S.H.U., Costa, M.M., Bárbaro,I.M. and Muniz, F.R.S., 2007. Genetic divergence in sesame based on morphological and agronomic traits. Crop Breed. Appl. Biotechnol. 7, 253261.

Bedigian, D., 2003. Evolution of sesame (Revisited): Domestication, diversity and prospects. Genetic Resour. Crop Evol. 50, 779-787.

Behera, S. K., 2009. Heterosis and Combining Ability Analysis in Sesamum. Post Graduate Thesis, Dept. of Plant Breeding and Genetics, OUAT, Bhubaneswar.

Das, P.K., 1990. A simple modified technique for selfing and hybridization in (Sesamum indicum L.). Andhra Agric. J. 37, 104-106.

Mishra. A.K., Sikarwar, R.S., 2001. Heterosis and combining ability analysis in sesame. Sesame Saffl. News Lett. 16, 15.

Mishra, D. R., 2016. Parental genetic diversity, heterosis and genetic analysis for quantitative traits in sesame (Sesamum 
indicum L.). Ph.D. Thesis submitted to the Utkal University, Vani Vihar, Bhubaneswar, India. pp.53-55.

Nayak, P.K., 2008. Genetic divergence, heterosis and combining ability studies in sesame (Sesamum indicum L.). Ph.D. Thesis, Dept. of Plant Breeding and Genetics, OUAT, Bhubaneswar.

Nupur, M., Bhat, K.V., Srivastava, P.S., 2010. Variation in fatty acid composition in Indian germplasm of sesame. J. Amer. Oil Chemists' Soc. 87(11), 1263-1269.

Padma Sundari, M., Kamala, T., 2012. Heterosis in Sesamum indicum L. Asian J. Agric. Sci. 4(4), 287-290.

Prajapati, N., Patel, N.C.G., Bhatt, A.B., Prajapati, K.P., Patel,
K.M., 2010. Heterosis in Sesame (Sesamum indicum L.). Int. J. Agric. Sci. 6(1), 91-93.

Saravanan, S., Nadarajan, N., 2002. Studies on heterosis in sesame (Sesamum indicum L.). Ind. J. Genet. 62, 271-272.

Senthil Kumar, P., Pushpa, R., Ganesan, J., 2003. Heterosis for yield and yield components in sesame (Sesamum indicum L.). Sesame Saffl. Newslett. 18, 12-14.

Singh, R.K., Choudhury, B.C., 1985. Biometrical Techniques in Genetics and Plant Breeding. International Bioscience Publisher, India. pp.63-68.

Solanki, Z.S., Gupta, D., 2003. Inheritance studies for seed yield in sesame. Sesame Saffl. Newslett. 18, 25-28.

\section{How to cite this article:}

Tripathy, S. K., Mishra, D. R., Mishra, D., Mohanty, S. K., Dash, S., Panda, S., Mohanty, M. R., Reshmi Raj, K. R., Pradhan, K. Ch., Swain, D., Mohapatra, P. M., 2016. Identification of potential crosses for sesame breeding. Int. J. Curr. Res. Biosci. Plant Biol. 3(7), 110-116. doi: http://dx.doi.org/10.20546/ijcrbp.2016.307.016 